\title{
M. PROTASOWICKI
}

\section{LONG-TERM STUDIES ON HEAVY METALS IN AQUATIC ORGANISMS FROM THE RIVER ODRA MOUTH AREA}

\author{
Institute of Ichthyology \\ Szczecin, Poland
}

Contents of $\mathrm{Hg}, \mathrm{Cd}, \mathrm{Pb}, \mathrm{Cu}$, and $\mathrm{Zn}$ were determined within 1984-1988 in plankton, zebra mussel (Dreisseno polymorpho), roach (Rutilus rutilus), bream (Abramis brama), and pikeperch (Lucioperca lucioperca) from different parts of the River Odra mouth area.

Mercury was determined with CV AAS and assays of the remaining metals were carried out with flame AAS.

In terms of their heavy metal contents, the organisms studied can be ordered in the following way: plankton $>$ mussel $>$ fish.

A downstream decrease in heavy metal content was observed in the plankton. Mercury contents in fish decreased downstream, too. Mercury, copper, and zinc contents in fish were species-dependent, the highest contents being recorded in roach.

Heavy metal dynamics in the plankton over the 5 years of study seems to evidence a gradual reduction in mercusy and zinc and an increase in cadmium and lead. However, the changes were not reflected in contents of the metals in fish. No definite trend could be revealed in $\mathrm{Hg}, \mathrm{Cd}, \mathrm{Pb}, \mathrm{Cu}$, and $\mathrm{Zn}$ dynamics in roach, bream, and pikeperch, nor a clear-cut pattern could be found with respect to the author's results published earlier.

\section{INTRODUCTION}

Similarly to other rivers discharging into the Baltic Sea, the Odra carries a number of pollutants, including heavy metals. Heybowicz and Rybinski (1988) estimated the annual load of those elements contributed by both natural and anthropogenous sources. Sartor et al. (1974) demonstrated heavy metals to enter rivers with atmospheric precipitation rinsing streets of cities. The ship-building industry, too, may contribute to the environmental pollution with heavy metals, as do other industries (Bellinger and Benham 1978). 
It is commonly known that an interaction exist between the heavy metal contamination of a habitat and heavy metal levels in organisms inhabiting it.

The present study was aimed at assessing the extent of heavy metal bioaccumulation in organisms occurring in the river Odra mouth area, and at detecting possible trends and patterns.

\section{MATERIAL AND METHODS}

Assays were made on plankton, a bivalve (Dreissena polymorpha), roach (Rutilus rutilus), bream (Abramis brama), and pikeperch (Lucioperca lucioperca).

The plankton was sampled in the spring and summer seasons of 1984-1988. The samples were taken with a plank ton net from 4 parts of the area (Fig. 1):

I. river Odra downstream of the city of Szczecin;

II. the Odra mouth;

III. the southern part of the Szczecin Lagoon;

IV. the entrance ot the Piastowski Canal.

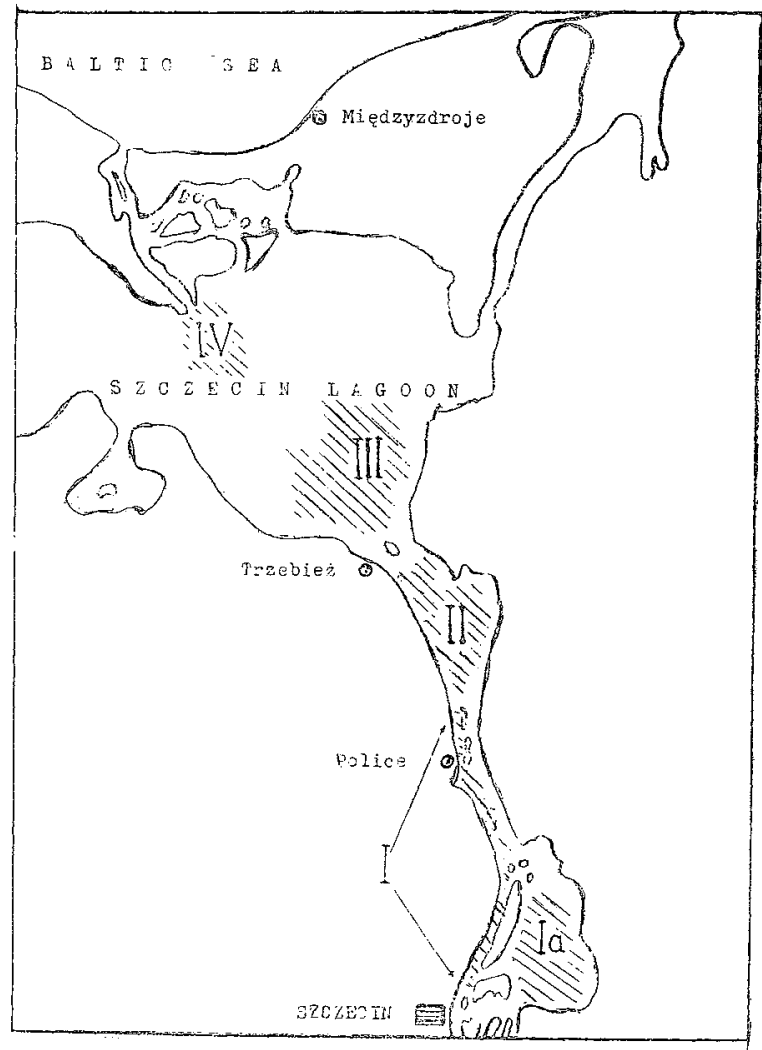

Fig. 1 . Sam: 
Dreissena polymorpha individuals were collected once a year within 1986-1988 from areas I, II, and III.

The fish caught, within 1984-1988, with gill nets from the Lake Dąbie (area Ia), Odra mouth (area II), and the southern part of the Szczecin Lagoon (area III). Fish samples were collected in spring, summer and autumn of each year except 1984 when autumn samples, consisting exclusively of pikeperch, were obtained only.

The assays were made on the entire plank ton samples, soft parts of 50 individuals of D. polymorpha, and dorsal muscles of 20 individuals of each fish species.

The samples were homogenized, frozen, and stored at $-20^{\circ} \mathrm{C}$ until analyzed.

Samples for mercury assays were combusted in $\mathrm{HNO}_{3}-\mathrm{HClO}_{4}$ as in Adrian (1971), the mercury content being determined with CV AAS. The remaining metals $(\mathrm{Cd}, \mathrm{Pb}, \mathrm{Cu}$, and $\mathrm{Zn})$ were determined with flame atomic absorption spectrometry, following dry combustion as described earlier (Protasowicki 1985). The heavy metal contents were determined from calibration curves plotted using the additives method. The contents in fish are expressed in $\mu \mathrm{g} / \mathrm{g}$ wet weight, while contents in plankton and bivalves are converted to $\mu \mathrm{g} / \mathrm{g}$ dry weight. The dry weight content was determined by drying at $105^{\circ} \mathrm{C}$. Each assay was made in triplicate. Relative errors were $4.11,7.43$, $10.01,4.26,3.80$, and $0.94 \%$ for $\mathrm{Hg}, \mathrm{Cd}, \mathrm{Pb}, \mathrm{Cu}, \mathrm{Zn}$, and dry weight determinations, respectively. The results obtained were treated statistically using methods given by Oktaba (1971).

\section{RESULTS}

The mean contents of heavy metals in plankton samples were found to be areaand sampling season-dependent (Table 1). Generally, the contents were observed to decrease downstream, although a departure from this pattern was occasionally observed in area IV. Over the five years of study $(n=20)$, the $\mathrm{Hg}$ and $\mathrm{Zn}$ contents were observed o decrease with time, the trends being best described by the following curvilinear regression equations and correlation coefficients:

Hg: $y=5.0274-1.8828 \ln t ; \quad r=-0.792$.

$\mathrm{Zn:} \quad \mathrm{y}=1282.8-428.1 \mathrm{ln} \mathrm{t} ; \quad \mathrm{r}=-0.610$

where $\mathrm{y}=$ heavy metal content

$\mathrm{t}=\mathrm{a}$ conventional value between 11 and 15 ascribed to each year, e.g.

$t_{1984}=11$ etc.

Over the same period of time, the cadmium and lead contents were observed to increase:

$\mathrm{Cd}: \quad \mathrm{y}=-12.8697+5.6013 \ln \mathrm{t} ;$

$r=0.437$

$\mathrm{Pb}: \quad \mathrm{y}=-479.964+201.51 \ln \mathrm{t} ; \quad \mathrm{r}=0.567$

No definite trend was detected with respect to the contents of copper. 
Heavy metals in total plankton from the river Odra mouth area, $\mu \mathrm{g} / \mathrm{g}$ dry weight

\begin{tabular}{|c|c|c|c|c|c|}
\hline \multirow{2}{*}{$\begin{array}{l}\text { Metal } \\
\text { Sampling area* }\end{array}$} & \multicolumn{5}{|c|}{ Year } \\
\hline & 1984 & 1985 & 1986 & 1987 & 1988 \\
\hline $\begin{array}{l}\text { Dry weight } \\
\text { content, \% }\end{array}$ & 3.88 & 5.67 & 6.88 & 5.43 & 7.70 \\
\hline $\mathrm{Hg}$ & 0.602 & 0.606 & 0.161 & nd & 0.029 \\
\hline II & 0.596 & 0.342 & 0.065 & nd & 0.055 \\
\hline III & 0.920 & 0.174 & 0.031 & 0.008 & 0.044 \\
\hline IV & 0.319 & 0.109 & 0.063 & nd & 0.063 \\
\hline $\mathrm{Cd}$ & 0.578 & 1.423 & 1.097 & 7.100 & 2.665 \\
\hline II & 0.627 & 1.056 & 0.911 & 1.569 & 1.111 \\
\hline III & 1.050 & 0.567 & 0.738 & 1.288 & 1.844 \\
\hline IV & 0.664 & 0.342 & 1.303 & 1.307 & 2.037 \\
\hline $\mathrm{Pb}$ & 3.54 & 19.23 & 130.31 & 58.33 & 105.36 \\
\hline II & nd & 14.91 & 100.88 & 22.80 & 55.59 \\
\hline III & nd & 12.25 & 11.85 & 14.98 & 45.54 \\
\hline IV & 4.10 & 1.76 & 19.63 & 9.37 & 83.47 \\
\hline $\mathrm{Cu}$ & 8.75 & 22.50 & 24.18 & 15.00 & 19.04 \\
\hline II & 9.46 & 24.25 & 17.25 & 13.25 & 11.57 \\
\hline III & 14.22 & 12.14 & 12.06 & 12.02 & 11.57 \\
\hline IV & 5.92 & 8.40 & 14.21 & 8.71 & 16.59 \\
\hline $\mathrm{Zn}$ & 347 & 213 & 208 & 194 & 161 \\
\hline II & 402 & 183 & 160 & 234 & 142 \\
\hline III & 237 & 171 & 110 & 207 & 100 \\
\hline IV & 214 & 110 & 141 & 81 & 130 \\
\hline
\end{tabular}

* sampling areas I-IV as in Fig. 1; nd - not detected

Table 2 presents the results obtained for $D$. polymorpha. In spite of a considerable variability of the data, no consistent pattern can be inferred due to their sporadic nature.

Table 3 summarizes data on trace metal levels in fish by species and area of capture, while Table 4 gives an overview of seasons-dependent changes in the levels irrespective of the fish species and area.

The mercury level is seen to depend on the three factors (species, area, season). The Lake Dąbie fish showed the higher mercury content, followed by that found in the fish caught in the river mouth and in the Szczecin Lagoon. Differences between mercury levels in the fish from the last two areas were negligible (Table 3). No area- 
Heavy metal content in bivalve (Dreissena polymorpha from the river Odra mouth area, $\mu \mathrm{g} / \mathrm{g}$ dry weight

\begin{tabular}{|c|c|c|c|}
\hline \multirow{2}{*}{$\begin{array}{c}\text { Metal } \\
\text { Sampling area* }\end{array}$} & \multicolumn{3}{|c|}{ Year } \\
\hline & 1986 & 1987 & 1988 \\
\hline Dry weight content, \% & 8.98 & 8.27 & 7.85 \\
\hline $\mathrm{Hg}$ & 0.080 & 0.038 & 0.094 \\
\hline II & 0.072 & - & 0.067 \\
\hline III & 0.077 & 0.099 & 0.059 \\
\hline $\mathrm{Cd}$ & 1.906 & 1.606 & 1.030 \\
\hline II & 1.504 & - & 2.231 \\
\hline III & 2.021 & 1.720 & 1.477 \\
\hline $\mathrm{Pb}$ & 16.49 & 5.44 & 3.40 \\
\hline II & 9.49 & - & 8.91 \\
\hline III & 4.59 & 6.21 & 6.79 \\
\hline $\mathrm{Cu}$ & 22.94 & 18.51 & 13.93 \\
\hline II & 21.06 & - & 24.20 \\
\hline III & 10.87 & 20.89 & 21.12 \\
\hline $\mathrm{Zn}_{\mathrm{n}}$ & 162 & 155 & 109 \\
\hline II & 169 & - & 174 \\
\hline III & 156 & 290 & 217 \\
\hline
\end{tabular}

* sampling areas I-III as in Fig. 1.

- lack of material

related differences were found with respect to $\mathrm{Cd}, \mathrm{Pb}, \mathrm{Cu}$, and $\mathrm{Zn}$ contents in fish muscles.

On the other hand, the data on mercury, copper and zinc contents in fish muscles reveal considerable interspecific differences. Roach muscles had higher contents than those found in bream and pikeperch. The interspecific differences in Cd and $\mathrm{Pb}$ proved non-significant (Table 3 ).

Considerable, statistically significant, fluctuations in heavy metal contents were revealed over the five years of study (Table 4). However, no directional multiannual trend or cyclic character could be detected in those fluctuations.

In terms of their heavy metal content, the organisms studied can be generally arranged in the following order:

Hg: plankton $>$ fish $>$ bivalves

$\mathrm{Cd}, \mathrm{Pb}$, and $\mathrm{Zn}$ : plankton $>$ bivalves $>$ fish

Cu: $\quad$ bivalves $>$ plankton $>$ fish

Thus the fish muscles show the weakest bioaccumulation of $\mathrm{Cd}, \mathrm{Cu}, \mathrm{Pb}$, and $\mathrm{Zn}$. 
Mean heavy metal content in fish from the river Odra mouth area

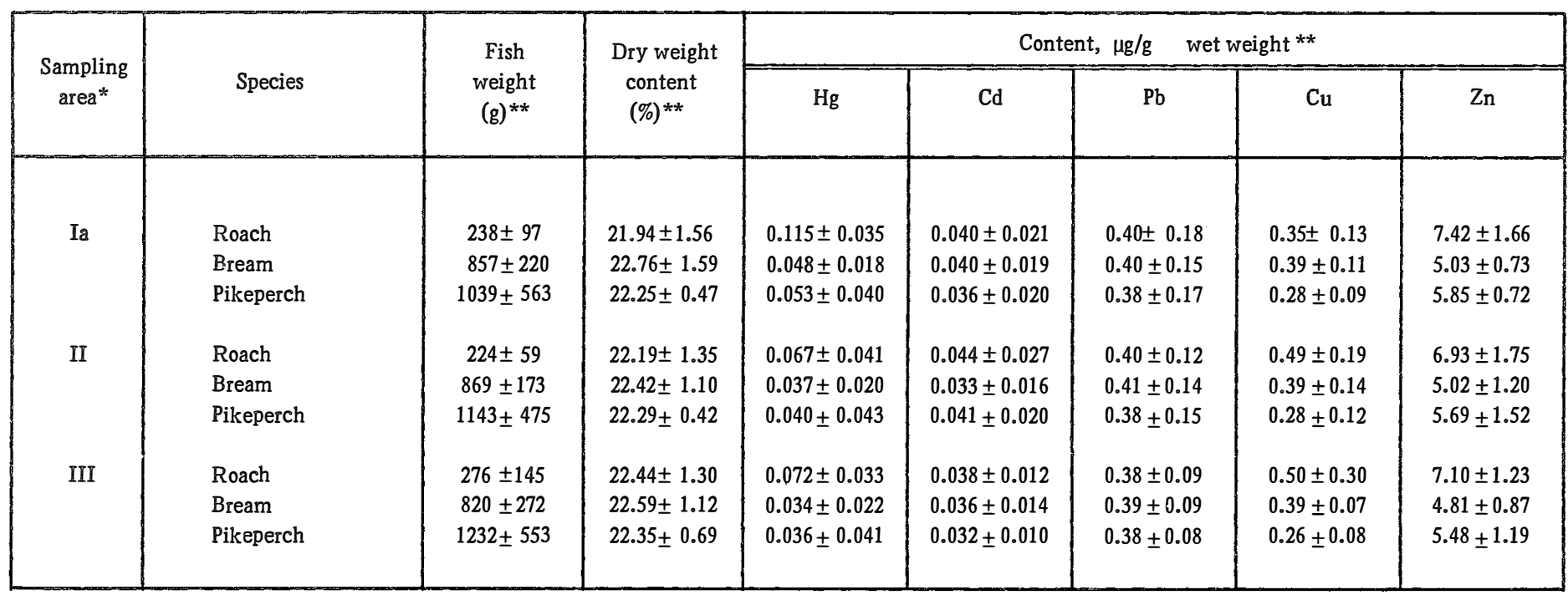

sampling areas Ia - III as in Fig. 1.;

** given as mean \pm standard deviation $(n=12)$ 
Changes of heavy metal content in fish from the river Odra mouth area during 1984-1988 years

\begin{tabular}{|c|c|c|c|c|c|c|}
\hline \multirow{2}{*}{\multicolumn{2}{|c|}{$\begin{array}{c}\text { Year } \\
\text { season* }\end{array}$}} & \multicolumn{5}{|c|}{ Content, $\mu \mathrm{g} / \mathrm{g}$ wet weight ** } \\
\hline & & $\mathrm{Hg}$ & $\mathrm{Cd}$ & $\mathrm{Pb}$ & $\mathrm{Cu}$ & $\mathrm{Zn}$ \\
\hline 1984 & $\mathrm{~A}$ & $0.009 \pm 0.004$ & $0.024 \pm 0.006$ & $0.16 \pm 0.10$ & $0.34 \pm 0.25$ & $4.77 \pm 0.74$ \\
\hline \multirow[t]{3}{*}{1985} & $S$ & $0.060 \pm 0.047$ & $0.048 \pm 0.023$ & $0.56 \pm 0.09$ & $0.45 \pm 0.35$ & $5.69 \pm 1.61$ \\
\hline & $\mathrm{Su}$ & $0.025 \pm 0.026$ & $0.036 \pm 0.009$ & $0.38 \pm 0.07$ & $0.51 \pm 0.24$ & $6.98 \pm 1.57$ \\
\hline & $\mathrm{A}$ & $0.020 \pm 0.026$ & $0.033 \pm 0.007$ & $0.33 \pm 0.07$ & $0.43 \pm 0.20$ & $6.19 \pm 1.68$ \\
\hline \multirow[t]{3}{*}{1986} & $S$ & $0.064 \pm 0.038$ & $0.036 \pm 0.026$ & $0.61 \pm 0.13$ & $0.38 \pm 0.17$ & $5.68 \pm 0.98$ \\
\hline & $\mathrm{Su}$ & $0.080 \pm 0.058$ & $0.032 \pm 0.014$ & $0.35 \pm 0.06$ & $0.32 \pm 0.14$ & $6.04 \pm 1.21$ \\
\hline & $\mathrm{A}$ & $0.063 \pm 0.038$ & $0.057 \pm 0.027$ & $0.38 \pm 0.03$ & $0.39 \pm 0.14$ & $5.70 \pm 1.21$ \\
\hline \multirow[t]{3}{*}{1987} & $S$ & $0.076 \pm 0.047$ & $0.015 \pm 0.007$ & $0.26 \pm 0.06$ & $0.28 \pm 0.08$ & $5.45 \pm 1.09$ \\
\hline & $\mathrm{Su}$ & $0.076 \pm 0.026$ & $0.038 \pm 0.004$ & $0.34 \pm 0.03$ & $0.31 \pm 0.07$ & $6.89 \pm 1.80$ \\
\hline & $\mathrm{A}$ & $0.093 \pm 0.038$ & $0.039 \pm 0.002$ & $0.37 \pm 0.03$ & $0.29 \pm 0.07$ & $6.87 \pm 1.01$ \\
\hline \multirow[t]{3}{*}{1988} & $S$ & $0.032 \pm 0.032$ & $0.031 \pm 0.004$ & $0.20 \pm 0.06$ & $0.37 \pm 0.07$ & $5.98 \pm 1.18$ \\
\hline & $\mathrm{Su}$ & $0.041 \pm 0.033$ & $0.032 \pm 0.012$ & $0.40 \pm 0.08$ & $0.31 \pm 0.08$ & $3.93 \pm 1.85$ \\
\hline & $\mathrm{A}$ & $0.044 \pm 0.038$ & $0.053 \pm 0.019$ & $0.52 \pm 0.03$ & $0.40 \pm 0.08$ & $5.70 \pm 0.94$ \\
\hline
\end{tabular}

* Season: A - autumn, S - spring, Su - summer;

$* *$ given as mean \pm standard deviation $(n=9)$ 


\section{DISCUSSION}

Different contents of heavy metals in plankton samples, and in fish muscles in the case of mercury, form an indirect evidence of a differential contamination of the Odra mouth area with those substances. The levels in plankton were observed to decrease downstream, which is an evidence of a dilution effect leading to decreased concentrations in water. However, this interpretation seems to be contradicted by the occasionally observed increased contents in plankton from the northern part of the Szczecin Lagoon as compared with those from the southern part. This is probably a result of the reversed currents carrying the polluted water southwards.

The lack of differences between $\mathrm{Cd}, \mathrm{Pb}, \mathrm{Cu}$, and $\mathrm{Zn}$ levels in fish from different parts of the area stems from the fact that changes of contents in muscles may be negligible even with high and widely differing concentrations of the metals in water. On the other hand, as shown in previous studies (Protasowicki and Chodyniecki 1988; Protasowicki and Chodyniecki in press) some internal organs clearly reflect the changes.

Earlier studies (Protasowicki 1982) demonstrated the lack of differences between contents of the four metals in muscles of bream from the Szczecin Lagoon and Odra mouth.

On one hand, it is optimistic to find decreasing trends in mercury and zinc levels in the plankton of the area; on the other, however, increased concentrations of cadmium and lead may be a cause of some anxiety. Fish muscles, however, failed to reflect those trends, some non-cyclic fluctuations in heavy metal levels being recorded only.

Comparisons of the present results with earlier data on mercury in pikeperch (Chodyniecki et al., 1975) and on cadmium, lead, copper, and zinc in bream (Protasowicki, 1987) of the Szczecin Lagoon show no significant differences to exist. The regression analysis, including the earlier data, failed to confirm the existence of differences, too. This, of course, does not exclude a possibility that certain trends can be detected over a longer period of observations, which should be expected based on trends already detected in the plankton.

The observed interspecific differences in the heavy metal accumulation result from different biological traits of the species studied, as pointed out in earlier studies on fish Protasowicki, 1986, 1987; Protasowicki et al., 1983.

\section{CONCLUSIONS}

1. The heavy metal contents in planktonic organisms were observed to decrease down the river Odra.

2. Over the five years of study, the mercury and zinc levels in the plankton were found to have decreased, while the cadmium and lead contents increased. No definite trend with respect to copper was detected. 
3. The differences and trends observed in the initial link of the trophic chain (plankton) were not reflected in organisms of the higher trophic level (fish), which is an evidence of the fish being better adapted to regulate their uptake and discharge of trace metals. Differences in mercury content in fish from various parts of the Odra estuary were an exception in this regard.

\section{REFERENCES}

Adrian W., 1971: A new wet digestion method for biological material utilizing pressure. At. Absorpt. Newsl., 10, 4: 96.

Bellinger $\mathbb{E}_{.} G_{\circ}, \mathbb{B} . \mathbb{R}$. Benham, 1978: The levels of metals in dockyard sediments with particular reference to the contributions from ship-bottom paints. Environ. Pollut., 15, 1: 71-81.

Chodyniecki A., M. Kurpios, M. Protasowicki, A. Ociepa, J. Juran, 1975: Studies on mercury content in selected fish species from Pomeranian Gulf and Szczecin Firth. Acta Ichthyol. Piscat., 5, 1: 51-57.

Heybowicz E. Jo Rybin̊nkki, 1988: Odpł̌yw metali Wisłą i Odrą 1987. Symp. nt. Usuwanie metali ciężkich z wody i ścieków, Polski Kom. Międzynar. Stowarzysz. Bad. Zan. i Ochr. Wód (IAWPRC), Warszawa, $235-244$.

Oktaba W., 1971: Metody statystyki matematycznej w doświadczalnictwie. PWN, Warszawa, 488 pp.

Protasowicki M., 1982: Zmiany zawartości wybranych metali ciężkich w rybach Bałtyku i strefy ujścia Odry. Zesz. Nauk. AR Szczecin, 93: 213-221.

Protasowicki M., 1985: Comparison of techniques of fish sample preparation for heavy metals analysis by flame AAS. Proc. 24th CSI, Garmisch-Partenkirchen 15-20.09.1985, 3 Th I $046: 548-549$.

Protasowicki M., 1996: The long-term observations on heavy metals content of fish in the Southern Baltic. I. Mercury. Baltic Sea Environ. Proc., 19: 62-75.

Protasowicki M., 1987: Wybrane metale ciężkie w rybach Bałtyku Południowego, Rozprawy AR Szczecin, $110,78 \mathrm{pp}$.

Protasowicki Mo, A. Chodyniecki 1988: Bioakumulacja Cd, Pb, Cu i $\mathrm{Zn}$ w karpiu-Cyprinus carpio L. w zależności od stężenia w wodzie i czasu ekspozycji.Zesz. Nauk. AR Szczecin, 133, 69-84.

Protasowicki M. A. Chodyraiecki (in press): Bioakumulacja kadmu w wybranych narządach karpia Cyprinus carpio L. przy podaniu per os. Roczn. Nauk Roln。, Ser. Rybactwo.

Protasowicki Mo, A. Chodyniecki, A. Ociepa, 1983: Metale ciężkie w rybach przemysłowych poławianych w latach 1976-1980. Zesz. Nauk. AR Szczerin, 103: 181-198.

Sartor J.D., G.B. Boyd, FoJ. Agardy, 1974: Water pollution aspects of street surface contaminants, J. Wat. Poll. Contr. Fed., 46, 3: 458-467.

Author's address:

Institute of Ichthyology

ul. Kazimierza Królewicza 4

71-550 Szczecin

Poland 